\title{
PENGARUH METODE PEMBELAJARAN DAN MOTIVASI TERHADAP HASIL BELAJAR SISWA PADA MATA PELAJARAN IPA
}

\author{
Eko Wiyono $^{1}$, Herawati ${ }^{2}$, Yanuardi $^{3}$ \\ ${ }^{1}$ Sekolah Pascasarjana Universitas Ibn Khaldun Bogor \\ Jl. KH. Sholeh Iskandar Km. 2 Kd. Badak, Bogor \\ ${ }^{1}$ Wiyonoeko14@gmail.com
}

\begin{abstract}
Abstrak: Penelitian ini bertujuan untuk mengetahui: (1)Apakah terdapat perbedaan hasil belajar IPA Peserta didik kelas V SD N Curug Cibinong yang dibelajarkan dengan Metode Problem Based Learning dan Cooperative Learning (2) Apakah tedapat pengaruh interaksi antara model pembelajaran dan motivasi belajar peserta didik kelas V SD N Curug Cibinong terhadap hasil belajar IPA ( 3) Apakah terdapat perbedaan hasil belajar IPA peserta didik kelas V SD N Curug Cibinong yang mempunyai motivasi belajar tinggi yang dibelajarkan dengan Metode Problem Based Learning dan Cooperative Learning (4) Perbedaan hasil belajar IPA peserta didik kelas V SD N Curug Cibinong yang memiliki motivasi belajar rendah yang dibelajarkan dengan Metode Problem Based Learning dan Cooperative Learning. Penelitian Menunjukan : (1) Metode pembelajaran Problem Based Learning Lebih unggul dibandingkan dengan Cooperative Learning, tampak bahwa nilai Fhitung dan sig. pada baris "Metode" berturut-turut sebesar 4,420 dan 0,043. Nilai Ftabel dengan nilai numerator $2-1=1$ dan denominator $36-2$ = 34 pada signifikansi 0,05 sebesar 4,01 . Karena nilai Fhitung $>$ Ftabel atau 4,420 > 4,01, dan nilai sig. 0,043 < 0,050 yang berarti menerima $\mathrm{H} 1$ dan menolak H0. Dengan demikian terdapat perbedaan Hasil belajar IPA pada peserta didik yang dibelajarkan dengan Metode pembelajaran problem based learning dan Metode pembelajaran cooperative learning dimana Hasil belajar IPA antara peserta didik yang menggunakan Metode pembelajaran problem based learning lebih baik daripada peserta didik yang menggunakan Metode pembelajaran cooperative learning.
\end{abstract}

Kata Kunci : Metode Pembelajaran Problem Based Learning, Hasil Belajar IPA.

\section{PENDAHULUAN}

\section{A. Latar Belakang}

Metode pembelajaran yang

digunakan sangat berpengaruh terhadap keberhasilan proses belajar. Pada dasarnya belajar adalah proses pengenalan dan memahami konsep konsep. Dalam proses pembelajaran peran guru sangat dominan baik dalam menyiapkan, menyusun dan memprogram proses pembelajaran di kelas. Kondisi pembelajaran berpusat pada guru (teacher centered), guru aktif, dan siswa cenderung bersikap pasif sehingga proses pembelajaran kurang melibatkan peran siswa secara fisik maupun mental dalam kegiatan pembelajaran. Siswa sebagai subyek 
belajar di programkan agar memperoleh hasil belajar yang guru (teacher centered), guru aktif, dan siswa cenderung bersikap pasif sehingga proses pembelajaran kurang melibatkan peran siswa secara fisik maupun mental dalam kegiatan pembelajaran. Metode Problem Based Learning adalah salah satu alternatif model pembelajaran yang diterapkan dalam proses pembelajaran mata pelajaran IPA. Metode Problem Based Learning lebih menekankan pada kegiatan -kegiatan yang berpusat dalam pemecahan masalah maupun pengembangan kreativitas belajar siswa. Penerapan metode Problem Based Learning dapat membantu guru dalam menyampaikan materi pembelajaran dengan menciptakan kondisi pembelajaran yang kondusif dalam menumbuhkan motivasi siswa untuk belajar lebih dalam, akan mendorong rasa ingin tahu siswa lebih lanjut dan mendorong siswa untuk berfikir kritis. Berkembangnya rasa ingin tahu, berfikir kritis, analisis dan rasa kepuasan dalam belajar siswa kiranya dapat digunakan dalam pengelolaan proses pembelajaran agar mencapai hasil belajar yang optimal.

Rendahnya hasil belajar dalam mata pelajajaran Ilmu Pengetahuan
Alam kemungkinan disebabkan oleh rendahnya proses belajar siswa.salah. Salah satu model pembelajaran yang diharapkan dapat meningkatkan hasil belajar siswa adalah dengan metode pembelajaran Problem Based Learning yang menekankan pada kegiatan kegiatan yang berpusat dalam pemecahan masalah maupun pengembangan kreativitas belajar siswa.

\section{B. Identifikasi Masalah}

Hasil Belajar peserta didik SD N CURUG kelas $\mathrm{V}$ tergolong rendah Khususnya untuk mata pelajaran IPA bila target Kriteria Ketuntasn Mininmal (KKM) masih dibwah rata-rata. Hal ini dimungkinkan beberapa factor diantaranaya: (1)Masih ada anggapan bahwa mata pelajaran IPA merupakan mata pelajaran yang di rasakan sulit untuk di pahami.(2)Sebagian besar siswa masih mengalami kesulitan dalam belajar IPA.(3)Sebagian guru masih banyak menggunakan metode konvensional. (4)Sebagian besar siswa masih banyak yang tidak senang bekerja sama dengan temannya dalam kelompok belajar(5)Kurang motivasi siswa dalam proses pembelajaran.(6)Kurangnya variasi guru dalam menerapkan metode pembelajaran yang baru dan relevan. 


\section{Perumusan Masalah}

Berdasarkan latar belakang masalah dan identifikasi masalah, dapat dirumuskan masalah sebagai berikut:

1. Apakah terdapat perbedaan hasil belajar IPA Peserta didik kelas V SD N Curug Cibinong yang dibelajarkan dengan Metode Problem Based Learning dan Cooperative Learning?

2. Apakah tedapat pengaruh interaksi antara model pembelajaran dan motivasi belajar peserta didik kelas V SD N Curug Cibinong terhadap hasil belajar IPA?

3. Apakah terdapat perbedaan hasil belajar IPA peserta didik kelas $\mathrm{V}$ SD N Curug Cibinong yang mempunyai motivasi belajar tinggi yang dibelajarkan dengan Metode Metode Problem Based Learning dan Cooperative Learning?

4. Apakah terdapat perbedaan hasil belajar IPA peserta didik kelas V SD N Curug Cibinong yang memiliki motivasi belajar rendah yang dibelajarkan dengan Metode Metode Problem Based Learning dan Cooperative Learning?

\section{TINJAUAN TEORI}

\section{A. Hasil Belajar Ilmu Pengetahuan}

Alam

hasil belajar adalah suatu akibat dari proses belajar dengan menggunakan alat pengukuran, yaitu berupa tes yang disusun secara terencana, baik tes tertulis, tes lisan maupun tes perbuatan (

Yulaelawati:2004)

Menurut Sudjana (2010) hasil belajar adalah kemampuan yang dimiliki siswa setelah menerima pengalaman belajar atau penilaian terhadap kemampuan siswa yang ditentukan dalam bentuk angka atau tingkat keberhasilan siswa dalam mempelajari mata pelajaran di sekolah yang dinyatakan dalam bentuk skor yang diperoleh dari hasil tes mengenai sejumlah pelajaran

Hasil Belajar IPA adalah suatu upaya peserta didik untuk mengetahui, memahami serta Mendemonstrasikan kebendaan dan gejala - gejala alam dengan cara sistematik dan teoritik yang diperoleh melalui pengamatan dan metode khusus.

B. Metode Pembelajaran Problem Based Learning

Problem based learning (PBL) adalah satu model yang mengembangkan para siswa "belajar 
untuk belajar," bekerja dengan cara menemukan dan menggunakan sumber kerja sama di dalam kelompok- belajar yang sesuai.

kelompok untuk mencari pemecahan masalah dalam dunia nyata.

C. Metode

Pembelajaran

Permasalahan ini digunakan untuk

Cooperative

menghubungkan pokok materi

Metode Cooperative Merupakan jenis pelajaran terhadap rasa keingintahuan pembelajaran kelompok yang siswa. PBL mempersiapkan para siswa digunakan untuk menggambarkan sebuah prosedur pembelajaran di mana untuk berpikir kritis dan secara analitis, dan untuk menemukan serta para pebelajar bekerja dengan yang menggunakan sumber belajar yang sesuai. Problem based learning (PBL), pada dasarnya, adalah satu model yang ditandai dengan penggunaan masalah dunia nyata sebagai suatu konteks bagi para siswa untuk belajar berpikir kritis dan trampil memecahkan masalah dan memperoleh pengetahuan tentang konsep yang penting dari apa yang dipelajari

Problem based learning merupakan inovasi dalam pembelajaran karena dalam PBL kemampuan berfikir siswa betul-betul di optimalisasikan melalui proses kerja kelompok atau tim yang sistematis, sehingga siswa dapat memberdayakan, mengasah, menguji, dan mengembangkan kemampuan berfikir secara berkesinambungan. Dengan PBL, para siswa memperoleh ketrampilan tentang belajar sepanjang hidup, termasuk kemampuan untuk lainnya dalam kelompok kecil dan saling menghargai untuk mencapai prestasi bersama.

Ada empat aspek dalam merancang cooperative learning yaitu interaksi guru dengan siswa, interaksi siswa dengan siswa, spesialisasi tujuan dan bahan, serta aturan permainan dan tanggung jawab (Rusman : 2010).

\section{Motivasi Belajar.}

Menurut Haria Mudjiman (2011) motivasi belajar adalah kekuatan pendorong dan pengarah perbuatan belajar. Motivasi belajar ini dapat di bedakan menjadi motivasi instrinsik dan ekstrintik motivasi intrinsic adalah dorongan dari dalam diri untuk menguasai kompetensiguna mengatasi masalah, sedangkan motivasi ekstrinsik sesuatu dari luar diri.

Motivasi belajar adalah
keseluruhan daya penggerak baik dari alam diri maupun dari luar siswa yang meliputi ketekunan, keuletan, minat 
dan mandiri yang menjamin kelangsungan dan memberikan arah pada kegiatan belajar, sehingga tujuan yang dikehendaki oleh subjek belajar itu dapat tercapai.

\section{METODOLOGI PENELITIAN}

\section{A. Tujuan Penelitian}

Penelitian ini bertujuan untuk menguji sebagai berikut:

1. Perbedaan hasil belajar IPA Peserta didik kelas $\mathrm{V} \quad \mathrm{SD} \quad \mathrm{N} \quad$ Curug Cibinong yang dibelajarkan dengan Metode Problem Based Learning dan Cooperative Learning

2. Pengaruh interaksi antara model pembelajaran dan motivasi belajar peserta didik kelas V SD N Curug Cibinong terhadap hasil belajar IPA

3. Perbedaan hasil belajar IPA peserta didik kelas $\mathrm{V} \quad \mathrm{SD} \quad \mathrm{N}$ Curug Cibinong yang mempunyai motivasi belajar tinggi yang dibelajarkan dengan Metode Metode Problem Based Learning dan Cooperative Learning.

4. Perbedaan hasil belajar IPA peserta didik kelas V SD N Curug Cibinong yang memiliki motivasi belajar rendah yang dibelajarkan dengan Metode Problem Based Learning dan Cooperative Learning.

\section{B. Tempat dan Waktu}

1. Tempat

Penelitian dilakukan di SDN CURUG Kec. Cibinong Kabupaten Bogor, dilaksanakan pada tahun pelajaran 2017 / 2018 dimulai pada bulan Oktober 2017

2. Waktu Penelitian

Penelitian dilakukan selama 5 bulan,terhitung dari bulan Oktober 2017 sampai dengan bulan februari 2018.

\section{Metodologi Penelitian}

Metode penelitian yang dipakai dalam penelitian ini adalah eksperimen dengan desain factorial $2 \mathrm{X}$ 2.Penelitian yang digunakan untuk mencari hubungan sebab dan akibat dengan memberikan Perlakuan khusus terhadap kelompok esperimen dan membandingkan dengan kelompok control.

Dengan perlakuan terhadap dua kelompok peserta didik, yang satu dibelajarkan dengan mengunakan metode Problem based learning, sedangkan kelompok yang lain diajarkan dengan menggunakan pembelajaran metode cooperative learning dan hasilnya berupa data penelitian yang diambil setelah penelitian seleai. Desain eksperiment 
yang digunakan adalah dapat digambarkan sebagai berikut :

\begin{tabular}{|c|c|c|}
\multicolumn{3}{|c|}{ Tabel 1 Desain Penelitian } \\
\begin{tabular}{|c|c|} 
Model \\
Pembelajara \\
(A)
\end{tabular} & $\begin{array}{c}\text { Model Problem } \\
\text { Based Learning } \\
\text { (A1) }\end{array}$ & $\begin{array}{c}\text { Model } \\
\text { Cooperative } \\
\text { (A2) }\end{array}$ \\
$\begin{array}{c}\text { Motivasi } \\
\text { Belajar (B) }\end{array}$ & A1B1 & A2B1 \\
\hline $\begin{array}{c}\text { Motivasi Tinggi } \\
\text { (B1) (B1) }\end{array}$ & A1B2 & A2B2 \\
\hline $\begin{array}{c}\text { Motivasi Rendah } \\
\text { (B2) }\end{array}$ & & \\
\hline
\end{tabular}

Keterangan :

A1B1 : Kelompok siswa yang mempunyai Motivasi tinggi yang diberi perlakuaan metode pembelajaran Problem Based Learning

A1B2 : Kelompok siswa yang mempunyai Motivasi rendah yang diberi perlakuan metode pembelajaran Problem Based Learning

A2B1 : Kelompok siswa yang mempunyai Motivasi tnggi yang diberi perlakuan metode pembelajaran

Cooperative Learning

A2B2 : Kelompok siswa yang mempunyai motivasi rendah yang diberi perlakuan metode pembelajaran Cooperative Learning

\section{Populasi dan Sample}

Populasi target pada penelitian ini adalah seluruh peserta didik kelas V SDN CURUG di Kecamatan Cibinong Kabupaten Bogor. Pengambilan Sampel dilakukan dengan pada penelitian ini adalah siswa kelas V semester 1 tahun pelajaran 2017/2018 sebanyak 3 kelas dengan jumlah siswa sekitar 90 siswa, yang terdiri 1 kelas, sebagai kelas eksperimen ,1 kelas lagi sebagai kelas control dan 1 kelas lagi sebagai kelas uji coba instrument penelitian. Penentuan kelompok perlakuan dalam penelitian ini melalui cara sebagai berikut:

1) Dari jumlah 3 kelas V SDN CURUG V Cibinong diambil 2 kelas secara acak.

2) Dari 3 kelas tersebut dilakukan acak untuk menetukan 1 kelas sebagai kelas eksperimen dan 1 kelas kontrol. Dengan jumlah peserta didik setiap kelas sebanyak 30 orang. Sampel penelitian ini adalah seluruh siswa kelas V semester 1 tahun pelajaran 2017/2018 sebanyak 3 kelas dengan jumlah siswa 90 siswa, yang terdiri dari 1 kelas eksperimen dan 1 kelas control 
dan 1 kelas lagi sebagai kelas uji coba instrument penelitian.

3) Pada tiap-tiap kelas baik kelas kontrol maupun kelas eksperimen dilakukan pretest motivasi belajar untuk menentukan kelompok subjek yang memiliki motivas belajar tinggi dan rendah. Setelah dilakukan pretest motivas belajar, skor yang diperoleh selanjutnya diurutkan dari skor tertinggi sampai terendah untuk menetapkan kelompok Tinggi dan Rendah yang dilakukan menurut Popham dengan cara $27 \%$ kelompok atas untuk kelompok peserta didik dengan motivasi belajar tinggi dan $27 \%$ kelompok bawah untuk kelompok peserta didik dengan minat belajar rendah. Hal ini dapat dilihat pada table 2 .

Tabel 2. Sampel Penelitian

\begin{tabular}{|l|l|l|l|}
\hline Perlakuan & $\begin{array}{l}\text { Model } \\
\text { Problem } \\
\text { Based } \\
\text { Motivasi belarning }\end{array}$ & $\begin{array}{l}\text { Model } \\
\text { Coperative }\end{array}$ & Total \\
\hline Tinggi & 8 & 8 & 16 \\
\hline Rendah & 7 & 7 & 14 \\
\hline Total & 15 & 15 & 30 \\
\hline
\end{tabular}

\section{HASIL PENELITIAN}

\section{A. Uji Hipotesis Penelitian}

Analisis data untuk menguji hipotesis pada penelitian ini menggunakan teknik Analisis Varians (ANAVA) dua jalur dengan bantuan SPSS 20.

\section{1) Pengujian Hipotesis Pertama}

Hipotesis pertama yang diajukan dalam penelitian ini yaitu terdapat perbedaan Hasil belajar IPA pada peserta didik yang dibelajarkan dengan Model pembelajaran problem based learning dan Model pembelajaran cooperative learning dimana Hasil belajar IPA antara peserta didik yang menggunakan Model pembelajaran problem based learning lebih baik daripada peserta didik yang menggunakan Model pembelajaran cooperative learning. Deskripsi data Hasil belajar IPA disajikan pada Tabel 3 berikut.

Tabel 3. Deskripsi Data Hasil belajar IPA

\begin{tabular}{|c|c|c|c|}
\hline \multirow[b]{2}{*}{$\begin{array}{l}\text { Motivasi } \\
\text { Belajar }\end{array}$} & \multicolumn{2}{|c|}{ Model pembelajaran (A) } & \multirow[b]{2}{*}{$\begin{array}{l}\text { Total } \\
\text { Baris (b) }\end{array}$} \\
\hline & $\begin{array}{l}\text { Problem } \\
\text { Based } \\
\text { Learning } \\
\left(A_{1}\right)\end{array}$ & $\begin{array}{l}\text { Cooperative } \\
\text { Learning }\left(\mathrm{A}_{2}\right)\end{array}$ & \\
\hline \multirow{4}{*}{$\begin{array}{l}\text { Tinggi } \\
\left(\mathrm{B}_{1}\right)\end{array}$} & $\mathrm{n}_{1}=9$ & $\mathrm{n}_{2}=9$ & $\begin{array}{l}\mathrm{nb}_{1}= \\
18\end{array}$ \\
\hline & $\Sigma X_{1}=220$ & $\Sigma X_{2}=147$ & $\begin{array}{l}\Sigma \mathrm{Xb}_{1}= \\
367\end{array}$ \\
\hline & $\begin{array}{l}\Sigma X_{1}^{2} \\
48400\end{array}$ & $\Sigma X_{2}^{2}=21609$ & 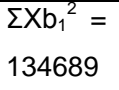 \\
\hline & $\bar{X}_{1}=24,44$ & $\bar{X}_{2}=16,33$ & $\bar{X} \mathrm{~b}_{1}$ \\
\hline
\end{tabular}




\begin{tabular}{|c|c|c|c|}
\hline \multirow{3}{*}{$\begin{array}{l}\text { Motivasi } \\
\text { Belajar }\end{array}$} & \multicolumn{2}{|c|}{ Model pembelajaran (A) } & \multirow{2}{*}{$\begin{array}{l}\text { Total } \\
\text { Baris (b) }\end{array}$} \\
\hline & $\begin{array}{l}\text { Problem } \\
\text { Based } \\
\text { Learning } \\
\left(\mathrm{A}_{1}\right)\end{array}$ & $\begin{array}{l}\text { Cooperative } \\
\text { Learning }\left(\mathrm{A}_{2}\right)\end{array}$ & \\
\hline & & & 20,39 \\
\hline \multirow{4}{*}{$\begin{array}{l}\text { Rendah } \\
\left(\mathrm{B}_{2}\right)\end{array}$} & $\mathrm{n}_{3}=9$ & $\mathrm{n}_{4}=9$ & $\begin{array}{l}\mathrm{nb}_{2}= \\
18\end{array}$ \\
\hline & $\Sigma X_{3}=138$ & $\Sigma X_{4}=158$ & $\begin{array}{l}\sum \mathrm{Xb}_{2}= \\
296\end{array}$ \\
\hline & $\begin{array}{l}\Sigma X_{3}^{2}= \\
19044\end{array}$ & $\Sigma X_{4}^{2}=24964$ & $\begin{array}{l}\Sigma \mathrm{Xb}_{2}{ }^{2}= \\
87616\end{array}$ \\
\hline & $\bar{X}_{3}=15,33$ & $\bar{X}_{4}=17,56$ & $\begin{array}{l}\bar{X} \mathrm{~b}_{2}= \\
16,44\end{array}$ \\
\hline \multirow{4}{*}{$\begin{array}{l}\text { Total } \\
\text { Kolom (k) }\end{array}$} & $\mathrm{nk}_{1}=18$ & $\mathrm{nk}_{1}=18$ & $n_{t}=36$ \\
\hline & $\Sigma \mathrm{Xk}_{1}=358$ & $\Sigma \mathrm{Xk}_{1}=305$ & $\begin{array}{l}\Sigma X_{t}= \\
663\end{array}$ \\
\hline & $\begin{array}{l}\Sigma \mathrm{Xk}_{1}{ }^{2}= \\
128164\end{array}$ & $\begin{array}{l}\Sigma{X k_{1}{ }^{2}}= \\
93025\end{array}$ & $\begin{array}{l}\Sigma X_{t}^{2}= \\
439569\end{array}$ \\
\hline & $\bar{X} \mathrm{k}_{1}=19,89$ & $\bar{X} \mathrm{k}_{1}=16,94$ & $\begin{array}{l}\bar{X} \quad \mathrm{t}= \\
18,42\end{array}$ \\
\hline
\end{tabular}

Keterangan:

$\mathrm{N}=$ Jumlah sampel

$\Sigma \mathrm{X}=$ Nilai hasil belajar

$\Sigma \mathrm{X}^{2}=$ Jumlah kuadrat hasil belajar

$\mathrm{X}^{-} \quad$ Rata-rata hasil belajar

Berdasarkan perhitungan data hasil tes di atas diperoleh rata-rata hasil belajar peserta didik yang mengikuti Model pembelajaran problem based learning sebesar 19,89, sedangkan ratarata hasil belajar peserta didik yang mengikuti Model pembelajaran cooperative learning sebesar 16,94. Hasil tersebut menunjukan bahwa hasil belajar peserta didik yang menggunakan Model pembelajaran problem based learning lebih tinggi dibandingkan hasil belajar peserta didik yang mengikuti Model pembelajaran cooperative learning dengan selisih rata-rata 2,94 .

Selanjutnya untuk mengetahui perbedaan hasil belajar antara peserta didik yang mengikuti Model pembelajaran problem based learning dengan Model pembelajaran cooperative learning dan pengaruh interaksi Model pembelajaran dan Motivasi Belajar peserta didik terhadap Hasil belajar IPA, dilakukan perhitungan analisis varians dua jalur (Anava). Hasil perhitungan dapat dilihat pada Table 4.

\section{Tabel 4. Hasil Perhitungan Anava 2 Jalur}

Tests of Between-Subjects Effects

Dependent Variable: HasilBelajar

\begin{tabular}{|l|l|l|l|}
\hline $\begin{array}{l}\text { Type III } \\
\text { Sum of } \\
\text { Squares }\end{array}$ & Df & $\begin{array}{l}\text { Mean } \\
\text { Square }\end{array}$ & \\
\hline $460.111^{\mathrm{a}}$ & 3 & 153.370 & 8.369 \\
12173.444 & 1 & 12173.444 & 664.258 \\
144.000 & 1 & 144.000 & 7.858 \\
81.000 & 1 & 81.000 & 4.420 \\
235.111 & 1 & 235.111 & 12.829 \\
586.444 & 32 & 18.326 & \\
13220.000 & 36 & & \\
1046.556 & 35 & & \\
\hline
\end{tabular}

a. R Squared $=.440$ (Adjusted R Squared $=.387$ )

Keterangan:

a) Corrected Model: Pengaruh Semua Variabel independen (Model pembelajaran, Motivasi Belajar dan Interaksi Model pembelajaran dengan Motivasi Belajar atau 
"Strategi*Efikasi") secara bersamasama terhadap variabel dependen (Hasil Belajar). Apabila Signifikansi $($ Sig. $)<0,05$ (Alfa $)=$ Signifikan. Hasil di atas 0,000 berarti Model valid.

b) Intercept: Nilai perubahan variabel dependen tanpa perlu dipengaruhi keberadaan variabel independen, artinya tanpa ada pengaruh variabel independen, variabel dependen dapat berubah nilainya. Apabila Signifikansi (Sig.) $<0,05$ (Alfa) $=$ Signifikan. Hasil di atas 0,000 berarti intercept signifikan.

c) Motivasi: Pengaruh Motivasi Belajar terhadap hasil belajar di dalam Model. Apabila Signifikansi (Sig.) $<0,05 \quad($ Alfa $)=$ Signifikan . Hasil di atas 0,009 berarti Motivasi Belajar berpengaruh signifikan.

d) Model: Pengaruh Model Pembelajaran terhadap hasil belajar di dalam Model. Apabila Signifikansi (Sig.) $<0,05$ (Alfa) $=$ Signifikan. Hasil di atas 0,043 berarti Model Pembelajaran berpengaruh signifikan.

e) Motivasi*Model:

Pengaruh Motivasi*Model terhadap hasil belajar. Apabila Signifikansi (Sig.) $<0,05($ Alfa $)=$ Signifikan. Hasil di atas 0,001 berarti Motivasi
Belajar*Model pembelajaran berpengaruh signifikan.

Berdasarkan hasil perhitungan anava 2 jalur di atas, tampak bahwa nilai Fhitung dan sig. pada baris "Model" berturut-turut sebesar 4,420 dan 0,043. Nilai Ftabel dengan nilai numerator 2-1 = 1 dan denominator 36$2=34$ pada signifikansi 0,05 sebesar 4,01. Karena nilai Fhitung >Ftabel atau $4,420>4,01$, dan nilai sig. $0,043<$ 0,050 yang berarti menerima $\mathrm{H} 1$ dan menolak H0, sehingga dapat disimpulkan bahwa terdapat perbedaan Hasil belajar IPA pada peserta didik yang dibelajarkan dengan Model pembelajaran problem based learning dan Model pembelajaran cooperative learning dimana Hasil belajar IPA antara peserta didik yang menggunakan Model pembelajaran problem based learning lebih baik daripada peserta didik yang menggunakan Model pembelajaran cooperative learning.

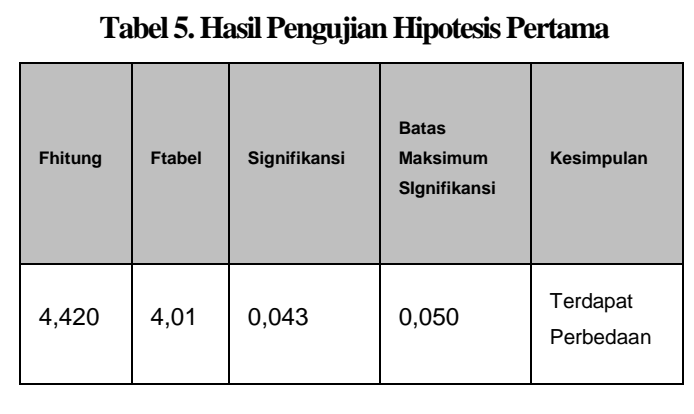

2) Pengujian Hipotesis Kedua 
Hipotesis kedua yang diajukan dalam penelitian ini yaitu terdapat interaksi antara Model pembelajaran dengan Motivasi Belajar Belajar terhadap Hasil belajar IPA.

Berdasarkan hasil perhitungan anava pada Tabel 4 tampak bahwa nilai Fhitung dan sig. pada baris "Motivasi*Model" berturut-turut sebesar 12,829 dan 0,001. Nilai Ftabel dengan nilai numerator $2-1=1$ dan denominator 36-2 = 34 pada signifikansi 0,05 sebesar 4,01. Karena nilai Fhitung > Ftabel atau 12,829> 4,01 , dan nilai sig. $0,001<0,050$ yang berarti menolak $\mathrm{H} 0$ dan menerima $\mathrm{H} 1$, sehingga dapat disimpulkan bahwa terdapat pengaruh interaksi antara Model pembelajaran dan Motivasi Belajar Siswa peserta didik terhadap Hasil belajar IPA.

Tabel 6. Hasil Pengujian Hipotesis Kedua

\begin{tabular}{|l|l|l|l|l|}
\hline Fhitung & Ftabel & Signifikansi & $\begin{array}{l}\text { Batas Maksimum } \\
\text { Slgnifikansi }\end{array}$ & Kesimpulan \\
\hline 12,829 & 4,01 & 0,001 & 0,050 & $\begin{array}{l}\text { Terdapat } \\
\text { Interaksi }\end{array}$ \\
\hline
\end{tabular}

Interaksi antara Model pembelajaran dengan Motivasi Belajar Siswa terhadap Hasil belajar IPA dapat digambarkan sebagai berikut.

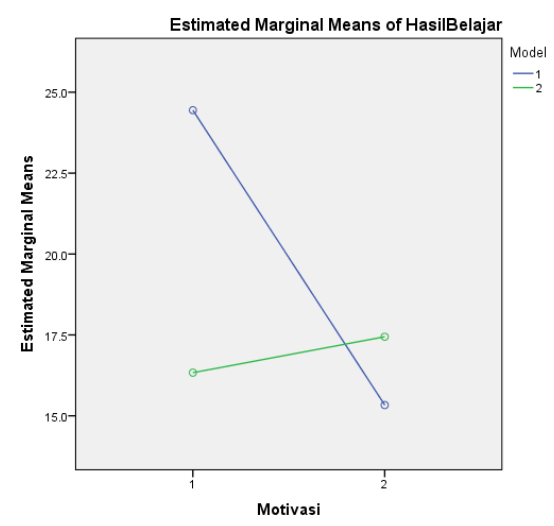

Gambar 1. Interaksi antara Model pembelajaran dengan Motivasi Belajar terhadap Hasil belajar IPA

\section{3) Pengujian Hipotesis Ketiga}

Hipotesis ketiga yang diajukan dalam penelitian ini yaitu Hasil belajar IPA pada peserta didik yang memiliki Motivasi Belajar tinggi lebih tinggi jika dibelajarkan dengan Model pembelajaran problem based learning daripada menggunakan Model pembelajaran cooperative learning.

Berdasarkan hasil perhitungan data penelitian yang dapat dilihat di Table 3 , diperoleh rata-rata Hasil belajar IPA peserta didik yang dibelajarkan dengan Model pembelajaran problem based learning pada peserta didik yang memiliki Motivasi Belajar Tinggi sebesar 24,44; lebih tinggi dibandingkan rata-rata Hasil belajar IPA peserta didik yang dibelajarkan dengan Model pembelajaran cooperative learning sebesar 16,33. Hasil tersebut menunjukan bahwa Hasil belajar IPA peserta didik yang 
memiliki Motivasi Belajar Tinggi yang

dibelajarkan dengan Model

pembelajaran problem based learning

lebih tinggi daripada peserta didik yang

dibelajarkan dengan Mode

pembelajaran cooperative learning

dengan selisih rata-rata 8,11 .
Karena hasil pengujian menyatakan terdapat interaksi antara Model pembelajaran dan Motivasi Belajar Siswa peserta didik terhadap Hasil belajar IPA, maka perlu dilakukan Uji Lanjut dengan menggunakan Uji Tukey. Hasil Uji Tukey dalam penelitian ini sebagai berikut.

Tabel 7. Hasil Uji Tukey

Multiple Comparisons

Dependent Variable: HasilBelajar

Tukey HSD

\begin{tabular}{|ll|l|l|l|l|l|}
\hline (I) Kelompok & (J) Kelompok & $\begin{array}{l}\text { Mean } \\
\text { Difference (I-J) }\end{array}$ & & Std. Error & Sig. & \multicolumn{2}{|l|}{$95 \%$ Confidence Interval } \\
\cline { 6 - 7 } & & & & & Lower Bound & Upper Bound \\
\hline \multirow{3}{*}{ A1B1 } & A1B2 & 9.111 & 2.018 & .000 & 3.64 & 14.58 \\
& A2B1 & $8.111^{*}$ & 2.018 & .002 & 2.64 & 13.58 \\
& A2B2 & $7.000^{*}$ & 2.018 & .008 & 1.53 & 12.47 \\
A1B2 & A1B1 & $-9.111^{*}$ & 2.018 & .000 & -14.58 & -3.64 \\
& A2B1 & -1.000 & 2.018 & .960 & -6.47 & 4.47 \\
& A2B2 & -2.111 & 2.018 & .724 & -7.58 & 3.36 \\
A2B1 & A1B1 & $-8.111^{*}$ & 2.018 & .002 & -13.58 & -2.64 \\
& A1B2 & 1.000 & 2.018 & .960 & -4.47 & 6.47 \\
& A2B2 & -1.111 & 2.018 & .946 & -6.58 & 4.36 \\
A2B2 & A1B1 & $-7.000^{*}$ & 2.018 & .008 & -12.47 & -1.53 \\
& A1B2 & 2.111 & 2.018 & .724 & -3.36 & 7.58 \\
& A2B1 & 1.111 & 2.018 & .946 & -4.36 & 6.58 \\
\hline
\end{tabular}

The mean difference is significant at the 0.05 level.

Dari hasil Uji Tukey pada Tabel 7, Tinggi yang dibelajarkan menggunakan terlihat bahwa kelompok A1B1 (Hasil Model pembelajaran cooperative belajar IPA peserta didik dengan learning), Means Difference sebesar Motivasi Belajar Tinggi yang 8,111; artinya selisih antara rata-rata dibelajarkan menggunakan Model hasil belajar kelompok A1B1 dengan pembelajaran problem based learning) kelompok A2B1 sebesar 8,111. dan kelompok A2B1 (Hasil belajar IPA Perbedaan signifikan ditandai dengan peserta didik dengan Motivasi Belajar tanda bintang (*). Dengan nilai sig $=$ 
$0.002<0,050$, hal ini menunjukkan bahwa terdapat perbedaan yang signifikan antara Hasil belajar IPA peserta didik dengan Motivasi Belajar Tinggi yang dibelajarkan menggunakan Model pembelajaran problem based learning dengan peserta didik yang menggunakan Model pembelajaran Table 8 berikut. cooperative learning.
Selanjutnya dilakukan Independent T Test yaitu uji komparatif atau uji beda untuk mengetahui adakah perbedaan mean atau rerata yang bermakna antara 2 kelompok bebas yang berskala data interval/rasio. Hasil Independen $\mathrm{T}$ Test dapat dilihat pada

Tabel 8. Independent T Test Motivasi Belajar Tinggi

Independent Samples Test

\begin{tabular}{|c|c|c|c|c|c|c|c|c|c|c|}
\hline & \multicolumn{2}{|c|}{$\begin{array}{l}\text { Levene's Test for } \\
\text { Equality of } \\
\text { Variances }\end{array}$} & \multicolumn{7}{|c|}{ t-test for Equality of Means } \\
\hline & & \multirow[t]{2}{*}{$F$} & \multirow[t]{2}{*}{ Sig. } & \multirow[t]{2}{*}{$t$} & \multirow[t]{2}{*}{ Df } & \multirow[t]{2}{*}{$\begin{array}{l}\text { Sig. (2- } \\
\text { tailed) }\end{array}$} & \multirow[t]{2}{*}{$\begin{array}{l}\text { Mean } \\
\text { Difference }\end{array}$} & \multirow[t]{2}{*}{$\begin{array}{l}\text { Std. Error } \\
\text { Difference }\end{array}$} & \multicolumn{2}{|c|}{$\begin{array}{l}95 \% \text { Confidence } \\
\text { Interval of the } \\
\text { Difference }\end{array}$} \\
\hline & & & & & & & & & Lower & Upper \\
\hline Nilai & $\begin{array}{l}\text { Equal } \\
\text { variances } \\
\text { assumed } \\
\text { Equal } \\
\text { variances not } \\
\text { assumed }\end{array}$ & 21.479 & .000 & $\begin{array}{l}3.972 \\
\\
3.972\end{array}$ & $\begin{array}{l}16 \\
8.794\end{array}$ & $\begin{array}{l}.001 \\
.003\end{array}$ & $\begin{array}{l}8.111 \\
8.111\end{array}$ & $\begin{array}{l}2.042 \\
2.042\end{array}$ & $\begin{array}{l}3.782 \\
3.475\end{array}$ & $\begin{array}{l}12.440 \\
12.747\end{array}$ \\
\hline
\end{tabular}

Dari Tabel 8 di atas, tampak bahwa pembelajaran cooperative learning nilai $\mathrm{t}$ hitung sebesar 3,972. Nilai $\mathrm{t}$ pada peserta didik yang memiliki tabel dengan nilai df $18-2=16$ pada Motivasi Belajar Tinggi.

signifikansi 0,05 sebesar 2,120. Karena

Dengan demikian, Hasil belajar nilai $\mathrm{t}$ hitung $>\mathrm{t}$ tabel atau 3,972 > IPA peserta didik yang memiliki 2,120 dapat disimpulkan bahwa Motivasi Belajar Tinggi yang terdapat perbedaan Hasil belajar IPA dibelajarkan dengan Model pada peserta didik yang dibelajarkan pembelajaran problem based learning dengan Model pembelajaran problem lebih tinggi dibandingkan Hasil belajar based learning dan Model IPA peserta didik yang dibelajarkan 
dengan Model pembelajaran learning pada peserta didik yang cooperative learning. Hal ini berarti memiliki Motivasi Belajar Rendah peserta didik dengan Motivasi Belajar sebesar 17,56, lebih tinggi Tinggi lebih cocok menggunakan dibandingkan rata-rata Hasil belajar Model pembelajaran problem based IPA peserta didik yang dibelajarkan learning.

Tabel 9. Hasil Pengujian Independent T-Test

\begin{tabular}{|l|l|l|}
\hline Thitung & Ttabel & Kesimpulan \\
\hline 3,972 & 2,120 & Terdapat Perbedaan \\
\hline
\end{tabular}

\section{4) Pengujian Hipotesis Keempat}

Hipotesis keempat yang diajukan dalam penelitian ini yaitu Hasil belajar IPA peserta didik yang memiliki Motivasi Belajar rendah lebih rendah jika dibelajarkan dengan Model pembelajaran problem based learning daripada menggunakan Model pembelajaran cooperative learning.

Berdasarkan hasil perhitungan data penelitian yang dapat dilihat di Tabel 3, diperoleh rata-rata Hasil belajar IPA peserta didik yang dibelajarkan dengan Model pembelajaran cooperative dengan Model pembelajaran problem based learning sebesar 15,33. Hasil tersebut menunjukan bahwa Hasil belajar IPA peserta didik yang memiliki Motivasi Belajar Rendah yang dibelajarkan dengan Model pembelajaran cooperative learning lebih tinggi daripada peserta didik yang dibelajarkan dengan Model pembelajaran problem based learning dengan selisih rata-rata 2,11 .

Karena hasil pengujian menyatakan terdapat interaksi antara Model pembelajaran dan Motivasi Belajar Siswa peserta didik terhadap Hasil belajar IPA, maka perlu dilakukan Uji Lanjut dengan menggunakan Uji Tukey. Hasil Uji Tukey dalam penelitian ini sebagai berikut.

Tabel 10 Hasil Uji Tukey

Multiple Comparisons

Dependent Variable: HasilBelajar

Tukey HSD

\begin{tabular}{|c|c|c|c|c|c|c|}
\hline \multirow[t]{2}{*}{ (I) Kelompok } & \multirow[t]{2}{*}{ (J) Kelompok } & \multirow{2}{*}{$\begin{array}{l}\text { Mean } \\
\text { Difference (I-J) }\end{array}$} & \multirow[t]{2}{*}{ Std. Error } & \multirow[t]{2}{*}{ Sig. } & \multicolumn{2}{|c|}{ 95\% Confidence Interval } \\
\hline & & & & & Lower Bound & Upper Bound \\
\hline \multirow{4}{*}{ A1B1 } & A1B2 & 9.111 & 2.018 & .000 & 3.64 & 14.58 \\
\hline & A2B1 & $8.111^{*}$ & 2.018 & .002 & 2.64 & 13.58 \\
\hline & A2B2 & $7.000^{*}$ & 2.018 & .008 & 1.53 & 12.47 \\
\hline & A1B1 & $-9.111^{*}$ & 2.018 & .000 & -14.58 & -3.64 \\
\hline \multirow[t]{2}{*}{ A1B2 } & A2B1 & -1.000 & 2.018 & .960 & -6.47 & 4.47 \\
\hline & A2B2 & -2.111 & 2.018 & .724 & -7.58 & 3.36 \\
\hline
\end{tabular}




\begin{tabular}{|c|c|c|c|c|c|c|}
\hline \multirow[t]{3}{*}{ (I) Kelompok } & \multirow[t]{2}{*}{ (J) Kelompok } & \multirow{2}{*}{$\begin{array}{l}\text { Mean } \\
\text { Difference (I-J) }\end{array}$} & \multirow[t]{2}{*}{ Std. Error } & \multirow[t]{2}{*}{ Sig. } & \multicolumn{2}{|c|}{ 95\% Confidence Interval } \\
\hline & & & & & Lower Bound & Upper Bound \\
\hline & A1B1 & $-8.111^{*}$ & 2.018 & .002 & -13.58 & -2.64 \\
\hline \multirow[t]{3}{*}{ A2B1 } & A1B2 & 1.000 & 2.018 & .960 & -4.47 & 6.47 \\
\hline & A2B2 & -1.111 & 2.018 & .946 & -6.58 & 4.36 \\
\hline & A1B1 & $-7.000^{*}$ & 2.018 & .008 & -12.47 & -1.53 \\
\hline \multirow[t]{2}{*}{ A2B2 } & A1B2 & 2.111 & 2.018 & .724 & -3.36 & 7.58 \\
\hline & A2B1 & 1.111 & 2.018 & .946 & -4.36 & 6.58 \\
\hline
\end{tabular}

${ }^{*}$. The mean difference is significant at the 0.05 level.

Dari hasil Uji Tukey pada Tabel 10, tidak terdapat perbedaan yang terlihat bahwa kelompok A1B2 (Hasil signifikan antara Hasil belajar IPA belajar IPA peserta didik dengan peserta didik dengan Motivasi Belajar Motivasi Belajar Rendah yang Rendah yang dibelajarkan dibelajarkan menggunakan Model menggunakan Model pembelajaran pembelajaran problem based learning) problem based learning dengan peserta dan kelompok A2B2 (Hasil belajar IPA didik yang menggunakan Model peserta didik dengan Motivasi Belajar pembelajaran cooperative learning.

Rendah yang dibelajarkan Selanjutnya dilakukan Independent menggunakan Model pembelajaran $\mathrm{T}$ Test yaitu uji komparatif atau uji cooperative learning), Means beda untuk mengetahui adakah Difference sebesar 2,111; artinya perbedaan mean atau rerata yang selisih antara rata-rata hasil belajar bermakna antara 2 kelompok bebas kelompok A1B2 dengan kelompok yang berskala data interval/rasio. Hasil A2B2 sebesar 2,111. Perbedaan Independen $\mathrm{T}$ Test dapat dilihat pada signifikan ditandai dengan tanda Table 11 berikut:

bintang $(*)$. Dengan nilai sig $=0,724>$

0,050, hal ini menunjukkan bahwa

Tabel 11. Independent $T$ Test Motivasi Belajar

Independent Samples Test

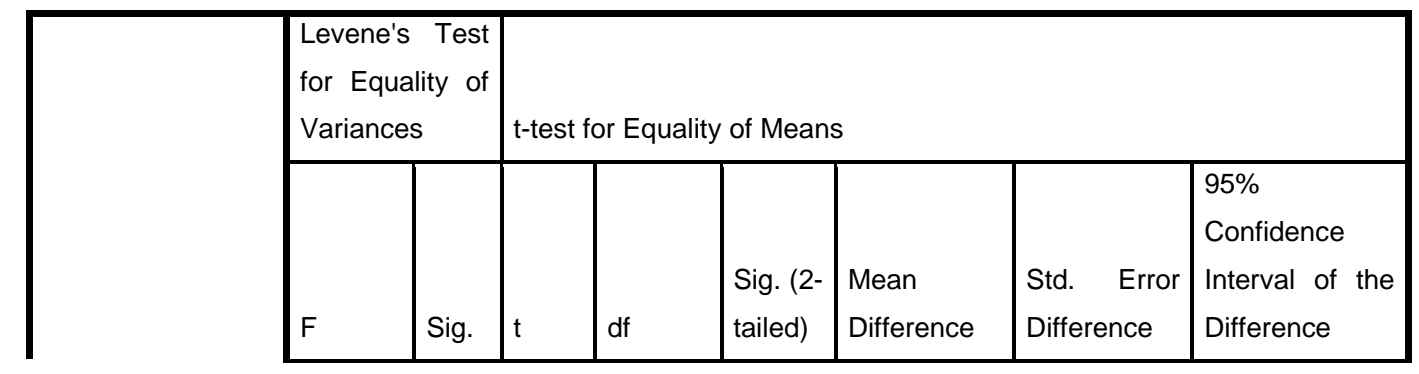




\begin{tabular}{|l|l|l|l|l|l|l|l|l|l|}
\hline Nilai $\begin{array}{l}\text { Equal } \\
\text { variances } \\
\text { assumed } \\
\text { Equal } \\
\text { variances } \\
\text { not } \\
\text { assumed }\end{array}$ & 25,921 &, 000 & 1,096 & 16 &, 289 & 2,222 & 2,028 & 6,522 & 2,078 \\
\hline
\end{tabular}

Dari Tabel 11 di atas, tampak dengan Motivasi Belajar Rendah lebih bahwa nilai t hitung sebesar 1,096. cocok menggunakan Model Nilai t tabel dengan nilai df $18-2=16$ pembelajaran cooperative learning. pada signifikansi 0,05 sebesar 2,120. Karena nilai $\mathrm{t}$ hitung $<\mathrm{t}$ tabel atau $1,096<2,120$ dapat disimpulkan bahwa tidak terdapat perbedaan signifikan antara Hasil belajar IPA pada peserta didik yang dibelajarkan dengan Model pembelajaran problem based learning dan Model pembelajaran cooperative learning pada peserta didik yang memiliki Motivasi Belajar Rendah

Tabel 12. Hasil Pengujian Independent T-Test

\begin{tabular}{|l|l|l|}
\hline Thitung & Ttabel & Kesimpulan \\
\hline 1,096 & 2,120 & Perbedaan tidak Signifikan \\
\hline
\end{tabular}

Hasil belajar IPA peserta didik yang memiliki Motivasi Belajar Rendah yang dibelajarkan dengan Model pembelajaran cooperative learning lebih tinggi dibandingkan Hasil belajar IPA peserta didik yang dibelajarkan dengan Model pembelajaran problem based learning walaupun perbedaan tersebut tidak signifikan. Hal ini berarti peserta didik

\section{SIMPULAN DAN SARAN}

\section{A. SIMPULAN}

Berdasarkan hasil analisis data pada bab sebelumnya, dapat disimpulkan sebagai berikut :

1. Hasil belajar IPA Peserta didik kelas V SD N Curug Cibinong yang dibelajarkan dengan Metode Problem Based Learning lebih tinggi dibandingkan dengan yang dibelajarkan dengan Metode Cooperative Learning.

2. Terdapat pengaruh interaksi antara Metode pembelajaran dan motivasi belajar peserta didik kelas V SD N Curug Cibinong terhadap hasil belajar IPA.

3. Hasil belajar IPA peserta didik kelas V SD N Curug Cibinong yang mempunyai motivasi belajar tinggi yang dibelajarkan dengan Metode Problem Based Learning lebih tinggi dibandingkan yang 
dibelajarkan dengan Metode Cooperative Learning.

Toeti Soekamto dan Udin Sarifudin

4. Hasil belajar IPA peserta didik kelas V SD N Curug Cibinong yang memiliki motivasi belajar rendah yang dibelajarkan dengan Metode Cooperative lebih tinggi dibandingkan yang dibelajarkan dengan Metode Problem Based

Winata putra,

Model

pembelajaran,cetakan pertama

Bandung PT,Rajagrafindo 2010: 78)

Imas Kurniasih Berlin Sani, Ragam pengembangan model pembelajaran, cetakan ketiga,(Kata pena Learning.

\section{DAFTAR PUSTAKA}

Gagne, Robert M., Leslie J. Briggs. 1985. Principles of Instructional Design. NewYork: Rinehant and Winston

Yulaelawati Ella, Kurikulum dan pembelajaran Edisi pertama ( Jakarta: Pakar Raya,2004)p.159

Iskandar, M,Buku paket IPA,Edisi ke empat ( Jakarta : 2001), p.23

Arief, Zaenal A. Teknologi Kinerja dalam proses pembelajaran ( Bogor: UIKA PRESS,2016)h,45

Miarso Yusufhadi, Menyemai Benih Teknologi Pendidikan ( Jakarta: PRENADAMEDIAN

GROUP,2004)h.528

Joyce, Bruce, Marsha Weil, Emily Calhoun. 2000. Models of Teaching. Boston: Allyn and Bacon Pearson Education Company
Klein Sephen, Method based Learning. University 2000. Educational Psychology: Efective Learning 3rd. Boston: McGraw Hill Co.

Sanjaya Wina, macam-macam model pembeljaran, cetakan kedua ( Jakarta:

erlangga 2006: 249)

Anderson, Albanese M., Mitchell S. Richard. 1993. Problem Based Learning: A Review of Literature on Its Outcomesand Implementations Issues, Acad. Medicine. 68(1), 52-81. (http://www.udel.edu/pbl/cte/spr96edit.html).( Diakses 12 Januari 2018).

Imas Kurniasih dan Berlin Sani,kumpulan metode pembelajaran kreatif dan inovatif (Bandung :Yrama Widya 2016:147) 
Rusman Model pembelajaran Cetakan

Pertama(Jakarta:Pt. Rajagrafindo persada,2010:140)

Borich, Gary D. 1999. Effective

Teaching Methods. Englewood Cliffs:

Merrill an Imprint of Prentice Hall.

Sanjaya Wina Model - model

pembelajaran ,Cetakan kedua(Bandung

Sinar c emerlang, 2008:230)

Cruickshank, Donald R., Deborah L.

Bainer, Kim K. Metcalf. 1999. The Art

of Teaching.Boston: Indiana

University

Makmum,Syamsuddin.A Makmum.

2002. Psikologi Pendidikan: Perangkat

Sistem Pengajaran Modul. Bandung:

PT. Remaja Rosdakarya

Irianto Agus. 2007. Statistik Konsep

Dasar dan Aplikasinya. Jakarta:

Kencana.

Lie Anita. 2002. Cooperative Learning

. Jakarta: PT. Grasindo.

Budiyono. 2003. Metodologi Penelitian pendidikan. Surakarta: UNS Press.
Depdiknas. 2005. Kurikulum Berbasis

Kompetensi. Jakarta: Diklat Mata Pelajaran.

Wina Sanjaya, macam-macam model pembelajaran, cetakan kedua ( Jakarta: erlangga 2008: 249),

Haria Mudjiman,Motivasi belajar( Jakarta :Prestasi pusaka,2011)h.121

Stephen N. Elliot, Thomas R. Kratochwill, Jean Littlefredl Cook, dan

John F. T ravers,Motivation

students,(2000: 333)

Sugiyono. Metode Penelitian Pendidikan (Bandung: Alfabeta.2012) h. 117

Arikunto, Suharsimi Prosedur Penelitian Suatu Pendekatan Praktik. (Jakarta: Rineka Cipta. 2010) h. 173

Driscoll, Mercy P. 1994. Psichology of Learning for Instruction. Boston:

Prasetya Irawan. 2001. Penilaian Hasil Belajar. Jakarta: Dirjen Pendidikan Tinggi Depdiknas

Suciati dan Prasetya Irawan. 2001. Teori Belajar dan Motivasi. Jakarta: PAU- PPAI Universitas Terbuka. 
Vol. 8 No. 2 Juli 2019 